\section{A HOARD FOR CHARON? THE ROMAN IMPERIAL HOARD FROM DESA (DOLJ COUNTY, ROMANIA)}

\begin{abstract}
In 1988, 122 silver denarii ranking from Nero to Commodus were confiscated by authorities from a person who was trying to sale these coins illegally at a local market. Following the study of the message on the coin reverse, the comparative analysis, the author suggests a deliberate selection for hoarding of coins that may have had an eschatological meaning for the individual that had assembled the hoard. Such a hypothesis may suggest that this hoard was not intended to have an economic purpose (e.g. savings, emergency hoard) but a funerary/votive one.
\end{abstract}

Keywords: funerary hoard, coin types, Roman Dacia.

$\mathbf{T}$ he hoard which is the subject of the present work belong to the category of those discoveries confiscated by authorities for illegal issues. A local from Desa (Dolj County, Romania) (maps 1-3) was trying to sale it, illegally, at the market in the city of Drobeta-Turnu Severin (Romania). In July 1988, the coins, 122 imperial denarii, entered the coin collection of the Iron Gates Region Museum from the same city. ${ }^{1}$

The hoard contains imperial denarii from Nero (AD 66-67) to Commodus. The latest coin was issued in AD $185 .^{2}$

The hoard from Desa was first mentioned among the numismatic finds of the year 1988 in Romania by Gh. Poenaru Bordea and B. Mitrea based on an information offered by I. Stîngă. At the time of publication, it was mention that the hoard was found at Desa and contained 222 silver coins (!). ${ }^{3}$

In September 1994, A. Popescu managed to study other 11 imperial denarii from the same hoard in a private collection in Bucharest. ${ }^{4}$

\footnotetext{
1 STÎNGĂ/BĂLTEANU 2002, 113.

2 GĂZDAC/NEAGOE 2020, catalogue.

3 POENARU BORDEA/MITREA 1989, 263, no. 32.

4 POPESCU 1996, 47-48.
}

\section{Cristian Găzdac}

Institute of Archaeology and Art History Cluj-Napoca, Romania cgazdac2000@yahoo.co.uk

DOI: $10.14795 /$ j.v7i1_SI.483

ISSN 2360 - 266X

ISSN-L 2360 - 266X 
Considering the way, the hoard entered the museum collection, the conditions of discovery are unknown. All it is known is that the hoard was found on the area of the commune of Desa (Dolj County, Romania). ${ }^{5}$

The village is located on the south-west part of Romania, circa $4 \mathrm{~km}$ from the left bank of the Danube River. (map 1)

The area of discovery is known as one with large evidence of archaeological evidence.

A possible Roman auxiliary fort and an attested Roman rural settlement are already known in this area. ${ }^{6}$ The artefacts collected (pottery, bronzes, coins) suggest a chronological segment from the Roman Republic to the $4^{\text {th }}$ century AD. ${ }^{7}$

The single coin finds known to be found here were minted during the Republic and Empire (by Augustus, Vespasian, Philip I, Constantine I, Licinius I, Constans and Constantius II). ${ }^{8}$

At the same time, the commune of Desa it is known for other hoards found in the area from various chronological horizons. In 1966, a hoard of republican denarii was mentioned by Gh. Popilian as being discovered here. ${ }^{9}$ In 2011, a hoard of $19^{\text {th }}$ century of 75 gold coins (Napoleon III, Austrian ducats, Ottoman issues). ${ }^{10}$ On the $14^{\text {th }}$ of January 2015 , it was discovered a complex of Celtic weaponry. ${ }^{11}$ On the $24^{\text {th }}$ of December, same year, another Roman imperial hoard of 220 denarii came to light on the territory of this locality. ${ }^{12}$

A detailed catalogue and illustration of the coins is provided in the forthcoming monograph of this hoard. ${ }^{13}$

In a 'traditional' fashion of analyzing

\footnotetext{
5 POENARU BORDEA/MITREA 1989, 263, no. 32.

6 TUDOR 1978, 274; POPESCU 1996, 47.

7 STÎNGĂ/BĂLTEANU 2002, 113.

8 POPEPSCU 1996, 48.

9 MITREA 1967, 384, no. 36 (Gh. Popilian); POPESCU 1996, 47.

10 http://www.ziare.com/cultura/stiri-cultura/tezaur-de75-de-monede-descoperit-in-oltenia-1113820.

11 https://cvlpress.ro/21.01.2016/vanatoare-de-comorila-desa-inca-un-tezaur-a-fost-descoperit/.

12 https://cvlpress.ro/21.01.2016/vanatoare-de-comorila-desa-inca-un-tezaur-a-fost-descoperit/.

13 GĂZDAC/NEAGOE 2020.
}

a coin hoard, one may have to explain the reason of hiding/burial and the non-recovery of this hoard.

On this line, the hoard from Desa can be framed within the horizon of hoards ending with coins of Commodus. The reign of Commodus was characterised by the conflicts between Commodus and the Germanic tribes. ${ }^{14}$ The similar date of the latest coins in some hoards made some scholars to suggest a common reason for burial: the last phase of the Marcomanic wars, before the peace of Commodus. ${ }^{15}$

An individual tragedy for hiding and non-recovery of the hoard from Desa cannot be totally ignored. The findspot is located on the road Drobeta - Sucidava (map 3) an area known forthemultitude of hoards discovered. ${ }^{16}$ Possible reason for non-recovery of these hoards could also be the robbery activity on roads. It can be easily noted that the roads in this area were quite unsafe. ${ }^{17}$ The epigraphic evidence from Drobeta indicate that there were travelers killed by thieves - "interfecti a latronibus". ${ }^{18}$

However, the analysis of coin types and the symbolism of the reverse iconography may suggest an alternative function of this hoard than an economic one.

A first striking aspect in this hoard is the presence, in quite a large number, of the Divus/Diva series. From 133 coins, 28 are (21\%) posthumous issues: 9 for emperors as divi: Antoninus Pius 6, Lucius Verus 1, Marcus Aurelius 2 and 19 for empresses as divae: Faustina I 18, Faustina II $1 .{ }^{19}$

In order to see whether this facet is a general or a specific pattern of hoarding in the Roman Empire or even beyond the Roman borders in the second half of the $3^{\text {rd }}$ century $\mathrm{AD}$, I used the largest database available

\footnotetext{
14 MÓCSY 1974, 193-194.

15 PREDA 1974, 90; POPILIAN/STAN-MIRCEŞTI 1989, 42.

16 GĂZDAC/NEAGOE 2018, 7; 22, map 4.

17 GĂZDAC 2012, 179 and map 9; GĂZDAC et al. 2015, 44.

18 RUSSU 1977, 71, 118

19 GĂZDAC/NEAGOE 2020 catalogue; plates.
} 
for the hoards of the Roman Empire: Coin Hoards of the Roman Empire. ${ }^{20}$ The filters in this web application were set to search for hoards similar to the one from Desa: 'terminal year' to AD 192; 'no. of coins' to 100-200 and 'person': Antoninus Pius (Divus), Faustina I (Diva), Lucius Verus (Divus), Faustina II (Diva), Marcus Aurelius (Divus).

The search returned 45 hoards from inside and outside the Roman Empire that fit to the search criteria. Most of these hoards have a very low percentage of posthumous issues, between $0.05 \%$ to $2 \%$. The highest percentages are offered by hoards discovered in...Sweden on the island of Gotland: ${ }^{21}$ Bjärs 1859 (10.18\%), ${ }^{22}$ Gandarve $1927(10.76 \%)^{23}$ and Bringsarve 1834 (12.05\%). ${ }^{24}$

Beside these 28 coins with a clear eschatological topic, another aspect that one must take into account when looking at the coins in the Desa hoard is the iconography on the coins' reverses.

Apart from its value as a currency and part of the crossing ritual in the afterlife, the coin could also be the bearer of a certain message that one could sent if he would like to express his sentiments/believes towards the gods or wishes to the person who just passed away.

It has been already demonstrated a possible deliberate selection of religiousbenevolent monetary types to be placed in graves. $^{25}$

The coins were minted by the authority - in the Roman imperial times mainly represented by the imperial house and some local authorities that issued provincial coins with permission granted by the emperor with a message that in most cases was linked to the image that the authority wanted to spread officially amongst the citizens. It has been clearly demonstrated that he imperial imagery penetrated into private contexts

\footnotetext{
20 http://chre.ashmus.ox.ac.uk.

21 Possible votive destination?

22 http://chre.ashmus.ox.ac.uk/hoard/15545.

${ }^{23}$ http://chre.ashmus.ox.ac.uk/hoard/15524.

24 http://chre.ashmus.ox.ac.uk/hoard/15539.

${ }^{25}$ ALFÖLDY-GĂZDAC/GĂZDAC 2009, 170.
}

through coins. ${ }^{26}$ If the issuer (the authority) was trying to send a deliberately designed message to the receptor (the coin user) it is in the human nature that the later one could have understood this message and regard the imagery also according to his own perceptions on different aspects of private life. The personal perception of coin message has been already pointed out regarding the distribution of coins with representations of imperial power in the time of crises. ${ }^{27}$ On the same line, also the coin offerings in the sanctuaries seem to have undergone, at some extent, a deliberate selection of coins' reverse types. ${ }^{28}$

Regarding the interpretation of coin message within eschatological context and not only, Claudia Perassi has suggested the presence of certain coin types in funerary contexts due to the message connected to various aspects of the funerary ritual and how the persons could regard the picture on coin as a symbol for a wish in the afterlife. ${ }^{29}$ An aspect of special interest is provided by the approach of this scholar on the level of alphabetization of the coin user. Combining literary and epigraphic sources Claudia Perassi demonstrates that for a person who wanted to use the coin as an offering item in Roman times a basic level of reading could have been useful but not compulsory. ${ }^{30}$ In some cases of coin offerings, it was obvious that the person who placed the coin in grave has selected it for meaning of the legend and the image depicted on reverse. On the other hand, coins were also selected only for those representations that were regarded as symbols for certain values and aspects on the afterlife. ${ }^{31}$

Returning to the coins in the hoard from Desa, can the analysis of imagery on the reverse of these coins reveal a deliberate selection of some of the coins to be hoarded?

A first representation that may have been easily interpreted by persons as having

\footnotetext{
${ }^{26}$ HOWGEGO 1995, 74.

27 MANDERS 2007, 281-284.

${ }^{28}$ KACZYNSKI/NÜSSE 2009, 93-107.

29 PERASSI 1999, 57-68.

30 PERASSI 1999, 48-52.

31 PERASSI 1999, 57-68.
} 
eschatological meaning is the altar. ${ }^{32}$

The altar is depicted on 15 coins from this hoard. Furthermore, while two coins has the altar as the only image on reverse, in other 12 cases, the altar is associated with other figures that are connected with the afterlife: Salus (6), Pietas (2), Vesta (1), eagle (3). On the same line, two more coins can be added to this category as instead the altar the libations take place at a tripod.

Following Claudia Perassi repertory of eschatological coin types, ${ }^{33}$ the Desa hoard includes 12 coins depicting Ceres, Pax (5), Fortuna (4), Vesta (3), Juno with peacock (3), Providentia (2), Felicitas (1), Libertas (1), peacock - not on a posthumous issue (1), Pietas (1), Priestly tools (1), Securitas (1), Spes (1), Victory on prow (1). Even a very seldom minted coin type of Tranquillitas is represented in this hoard by two coins.

Other three coins, may bring to our attention the old concept about the equality (Aequitas) of people during the last journey. ${ }^{34}$ Although on all three coins the image is the same - female holding scales and cornucopiae - on one of them the inscription mentions MONETA AVG, which means that the female is the personification of Moneta and not Aequitas. However, for the person hoarding these coins (possible, an illiterate), it was, probably, the image that led to the selection of that coin and not its inscription.

A series of eight coins may also be taken into account for a possible connection with the funerary ritual. The message or the image on the reverse refers, officially, to the generosity of the emperor: Liberalitas Augusti, Annona, modius. These coins could have been selected for what H. Nibley would call the private sparsiones (throwing things as donative). ${ }^{35}$ These sparsiones occurred at celebrations marking 'rite de passage' in a family, ${ }^{36}$ and death was one of them.

With 91 coins - out of 133 - that may be

\footnotetext{
32 PERASSI 1999, 58.

33 PERASSI 1999, 57-64.

34 GĂZDAC 2014, 99.

35 NIBLEY 1945, 516.

${ }^{36}$ NIBLEY 1945, 516.
}

connected with eschatological topics, it seems that the hoard from Desa may have served, in fact, as a funerary hoard and not necessarily as one with economic function (e.g. savings hoards, emergency hoards etc.). If this is the case, such a hoard was not deposited in order to be recovered at a later date. Thus, the hoard from Desa should be removed from the category of hoards buried/hidden and not recovered due to a violent event (e.g. was, invasion, raid, robbery etc.).

Is this hoard a single case? No. Probably, the best analogy is the small hoard discovered in 2005 in the city of Mangalia (Constanța County, Romania). ${ }^{37}$

In a ceramic jug were found 15 imperial denarii belonging to issuers from Nero to Hadrian. ${ }^{38}$

The first interesting aspect about this finding it is its archaeological context. The hoard was discovered in an ancient inhumation tomb located 200-300 m westward from the western limit of the Roman and Byzantine necropolis of Callatis, Roman province of Lower Moesia (nowadays, Mangalia). The jug was found near the dead's head. ${ }^{39}$ No other artefacts were discovered in the grave.

I this case the archaeological context proves beyond any doubts that this coin assembly can be considered a funerary hoard.

Therefore, one should analyses the coin types in this hoard to see whether there is a connection between the imagery on coins and the functionality of this hoard placed within a funerary environment.

Ten denarii out of 15 present a clear eschatological imagery: galley (as the Charon's boat) (1), ${ }^{40}$ Ceres/Annona (1), Pietas (1), Providentia (1), Salus (2), Securitas (2), priestly tools (1). Even one of the rarest posthumous issues that have been minted Galba for Diva Livia ${ }^{41}$ - found a place in this hoard.

\footnotetext{
37 PETAC et al. 2008, 39-47.

38 PETAC et al. 2008, 39-41.

39 PETAC et al. 2008, 39.

40 GĂZDAC 2014, 100.

41 PETAC et al. 2008, 40, no. 2 (mistaken for a Diva Julia); 46, photo 2.
} 
The above evidence indicates that there was a deliberate selection of coins with a possible eschatological meaning for this hoard placed in a grave.

The strong connection between the coin types and the archaeological context indicate a specific human behavior in selecting certain coins when deciding to place a hoard in a funerary environment.

Coming back to the hoard from Desa, it can be suggested that it could be easily defined as a funerary hoard.

However, in the absence of any information on the context of discovery and the originally number of coins, this possibility can be seen only as a plausible hypothesis.

\section{ACKNOWLEDGMENTS:}

The research was carried out within the research grants UEFISCSDI PN-III-P4-IDPCE-2016-0021.

\section{REFERENCES}

ALFÖLDY- GĂZDAC/GĂZDAC 2009

Alföldy- Găzdac, Á./Găzdac, C.: Coins in Funerary Contexts. The Case of Brigetio. In: Bíró, S. (ed.): EX OFFICINA...Studia in honorem Dénes Gabler (Budapest: Mursella Régészeti Egyesület), 161-174.

GĂZDAC 2012

Găzdac, C.: 'War and Peace'! Patterns of Violence through Coin Hoards Distribution. The Middle and Lower Danube from Trajan to Aurelianus, Istros 18, 165-198.

GĂZDAC 2014

Găzdac C.: Did Charon Read His Obol? The Message of Coin Offering in Roman Graves from Pannonia, Dacia 58, 95-140.

GĂZDAC ET AL. 2015

Găzdac, C./Alfödy-Găzdac, Á./Neagoe, M./ Neagoe, O.: Drobeta. The never abandoned city of Roman Dacia [Coins from Roman Sites and Collections of Roman Coins from Romania 9]. (Cluj-Napoca: Mega Publishing House).

GĂZDAC/NEAGOE 2018

Găzdac, C./Neagoe, M.: Wealthy or not in a time of turmoil? The Roman imperial hoard from Gruia (Mehedinți County, Romania). (Oxford: Archaeopress).

GĂZDAC/NEAGOE 2020
Găzdac, C./Neagoe, M.: The Roman Imperial Hoard from Desa [Coins from Roman Sites and Collections of Roman Coins from Romania 13] (Cluj-Napoca: Mega Publishing House). Forthcoming.

HOWGEGO 1995

Howgego, Ch.: Ancient history from coins (London - New York: Routledge).

KACZYNSKI/NÜSSE 2009

Kaczynski, B./Nüsse, M.: Reverse type selection in sanctuaries? A study of antoniniani found in various contexts. In: von Kaenel, M./Kemmers, F. (eds.): Coins in context I. New perspectives for the interpretation of coin finds [Studien zu Fundmünzen der Antike 23] (Mainz: von Zabern), 93-107.

MANDERS 2007

Manders, E.: Mapping the representation of Roman imperial power in the times of crises. In: Hekster, O. (ed.): Crisis and the Roman Empire. Proceedings of the seventh workshop of the International Network Impact of Empire (Nijmegen, June 20-24, 2006) (Leiden-Boston: Brill), 275-290.

\section{MITREA 1967}

Mitrea, B.: Découvertes récentes et plus ancienne des monnaies antiques et byzantines en Roumanie, Dacia 11, 377-394. MÓCSY 1974

Mócsy, A.: Pannonia and Upper Moesia. (Boston-London: Routledge \& Kegan Paul). NIBLEY 1945

Nibley, H.: Sparsiones. Classical Journal 40/9. 515-543.

\section{PERASSI 1999}

Perassi, Cl.: Monete nelle tombe di età romana imperial: casi di scelta intenzionale sulla base dei soggetti e delle scritte? In: Dubuis, O./Frey-Kupper, S./Perret, G. (eds.): Trouvailles monétaires des tombes. Actes du deuxième colloque international du Groupe Suisse pour l'étude des trouvailles monétaires (Neuchâtel, 3-4 mars 1995) (Lausanne: du Zèbre), 43-69.

PETAC et al. 2008

Petac, E./Ionescu, M.,/Alexandru, N./ Constantin, R./Alexiu, Al.: The funerary coin hoard discovered in 2005 at Mangalia, Constanţa County, Cultură şi Civilizaţie la Dunărea de Jos 26, 39-47

POENARU BORDEA/MITREA 1989

Poenaru Bordea, Gh./Mitrea, B.: Dé- 
couvertes monétaires en Roumanie - 1988 (XXXIII), Dacia 33/1-2, 259-266.

POPESCU 1996

Popescu, A.: Denari romani imperiali din tezaurul găsit la Desa (jud. Dolj), Cercetări Numismatice 7, 47-48.

POPILIAN/STAN-MIRCEŞTI 1989

Popilian, Gh./Stan-Mircești, I.: Tezaurul de monede romane imperiale de la Butoieşti (județul Mehedinţi), Studii și Cercetări de Numismatică 9, 37-42.

PREDA 1974

Preda, C.: Tezaurul monetar din epoca romană descoperit la Gârla Mare (Jud. Mehedinţi). Historica 3, 67-91.

\section{RUSSU 1977}

Russu, I.I.: Inscripțiile Daciei romane. vol. III/1. (Bucureşti: Editura Academiei).

STÎNGĂ/BĂLTEANU 2002

Stîngă, I./Bălteanu, D.: Tezaurul de denari romani imperiali de la Desa (jud. Dolj), Drobeta 11-12, 113-119.

\section{TUDOR 1978}

Tudor, D.: Oltenia romană, 4th edition. (București: Editura Academiei Republicii Socialiste România).

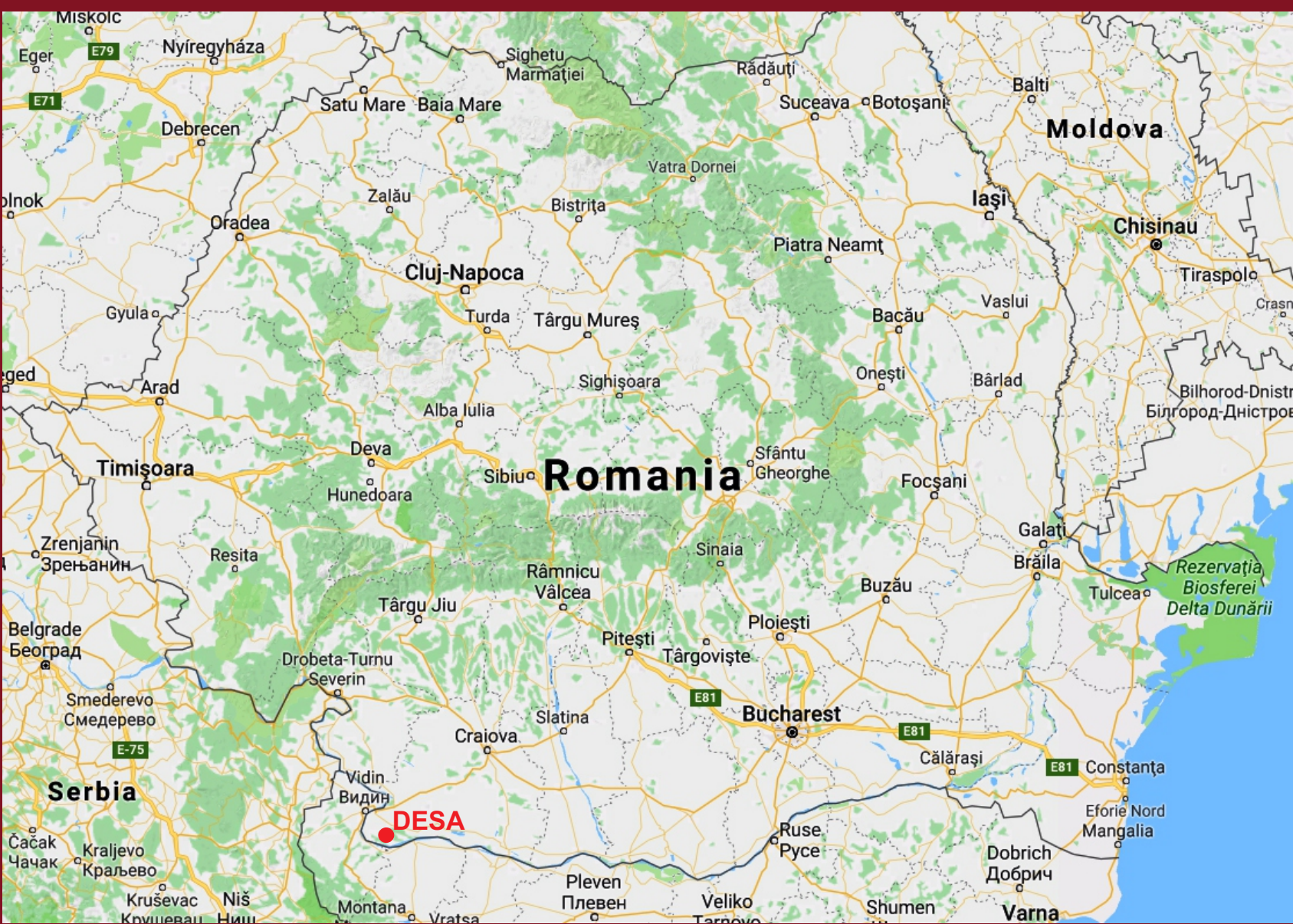

Map 1. Map of Romania pointing the location of Desa village (Google Maps) 


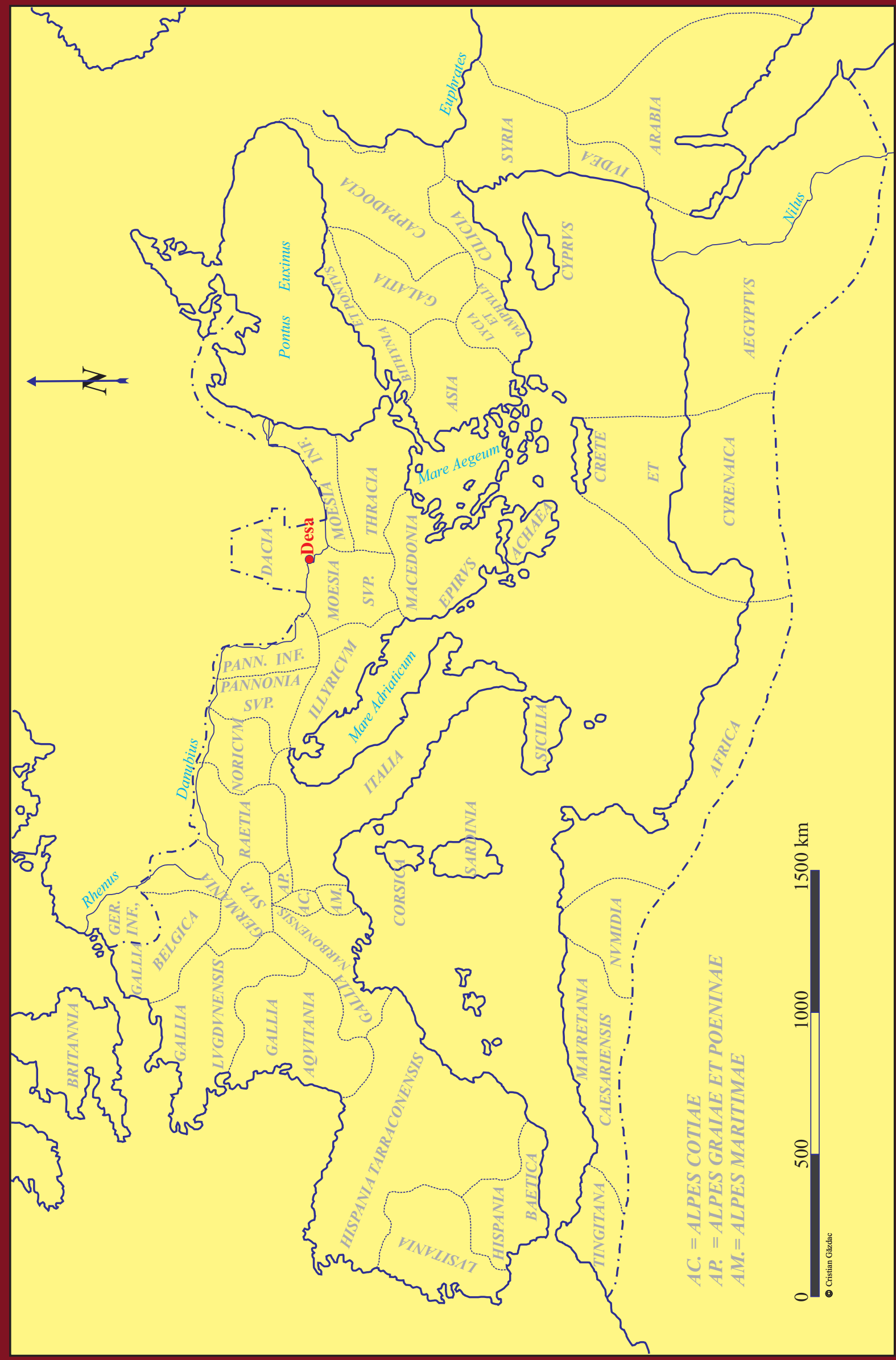

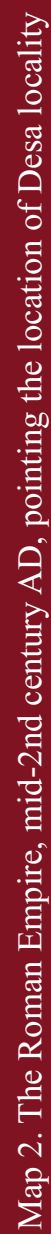




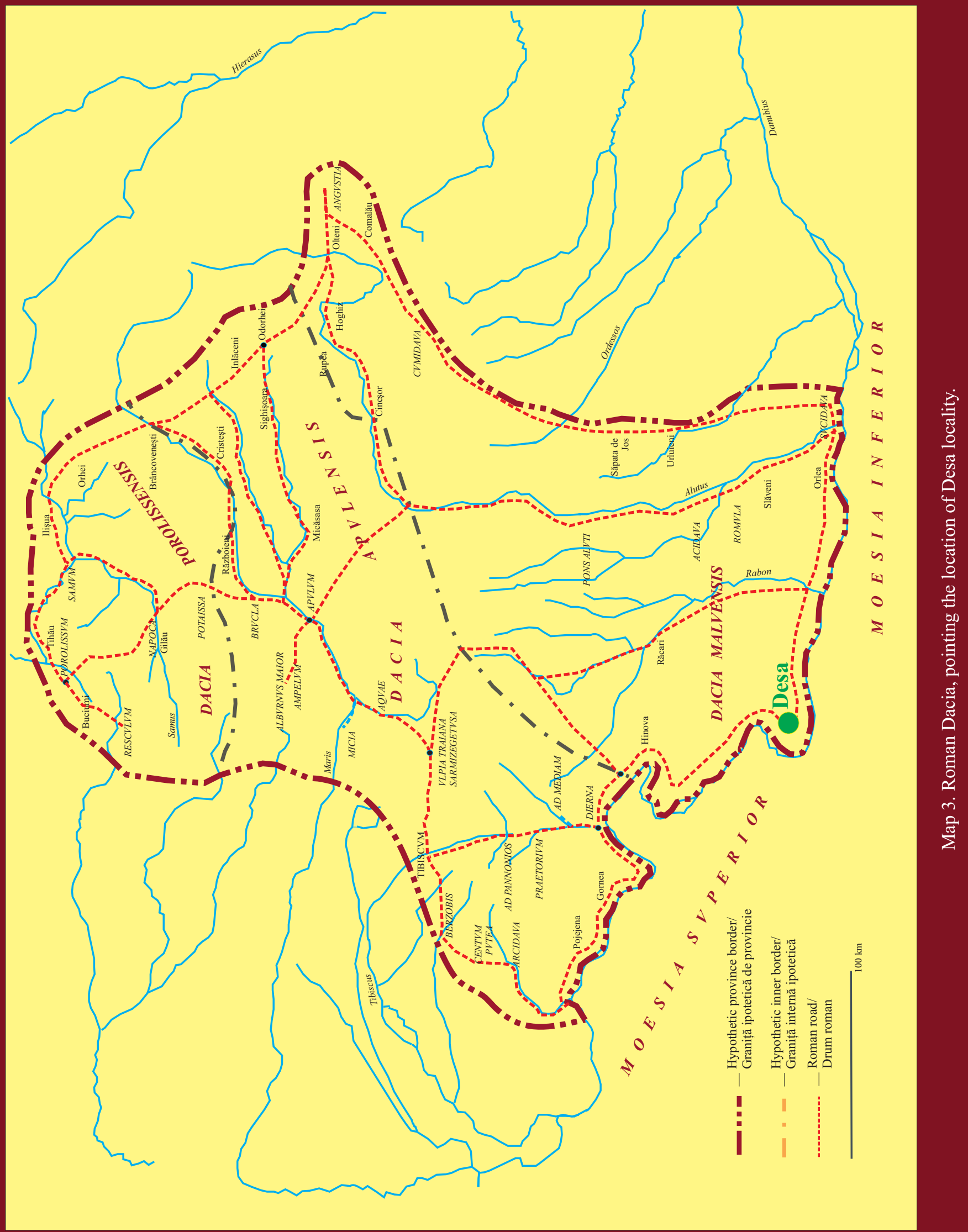

